\title{
Hypotensive Effect of Captopril and Decreased Rat Uterine Bradykinin Receptors
}

\author{
Minoru Yasujima, ${ }^{*}$ P. Geoffrey Matthews and \\ Colin I. JoHnston \\ Monash University Department of Medicine, Prince \\ Henry's Hospital, Melbourne, Victoria 3004, Australia
}

\begin{abstract}
Yasujima, M., Matthews, P.G. and Johnston, C.I. Hypotensive Effect of Captopril and Decreased Rat Uterine Bradykinin Receptors. Tohoku J. exp. Med., 1984, 144(2), 119-127 — To determine the role of local bradykinin at the level of the vascular smooth muscle receptors in the hypotensive effect of captopril, we assessed the effects of prolonged intravenous infusions for up to 7 days of bradykinin $(0.1 \mu \mathrm{g} / \mathrm{min})$ and captopril $(1.7 \mu \mathrm{g} / \mathrm{min})$ on systolic blood pressure and uterine bradykinin receptors in normotensive rats. Bradykinin infusion was associated with a transient fall in systolic blood pressure at Day $1(117.5 \pm 2.8$ $\mathrm{mmHg}$ vs. $125.8 \pm 1.7, p<0.05)$ and returned to control levels by Day 3 . Following captopril infusion there was a similar but more persistent fall in systolic blood pressure $(115.3 \pm 2.4 \mathrm{mmHg}$ vs. $125.8 \pm 1.7, p<0.01$ at Day 1 and $111.0 \pm 2.4 \mathrm{mmHg}$ vs. $125.0 \pm 1.9, p<0.001$ at Day7). After 2 days of bradykinin infusion the number of bradykinin receptors was decreased $(39.9 \pm 2.1 \mathrm{fmol} / \mathrm{mg}$ protein vs. 49 . $9 \pm 2.4, p<0.01$ ) and returned to controls at Day 7 , while captopril infusion induced a prolonged decrease $(42.3 \pm 1.8 \mathrm{fmol} / \mathrm{mg}$ protein vs. $49.9 \pm 2.4, p<0.05$ at Day 2 and $38.8 \pm 2.4 \mathrm{fmol} / \mathrm{mg}$ protein vs. $44.5 \pm 1.3, p<0.05$ at Day 7$)$. Present results suggest that the increased vascular tissue level of bradykinin can contribute directly to the acute hypotensive effect of captopril. However, it may play only a minor role for the chronic hypotensive effect of captorpil._ _ angiotensin converting enzyme inhibitor; captopril; local bradykinin levels; uterine smooth muscle; bradykinin receptors
\end{abstract}

Bradykinin lowers the systemic arterial blood pressure in all animal species tested (Stewart 1979). The hypotensive effect of bradykinin is the net result of its actions on smooth muscle in arterioles, venules and small vessels.

Captopril (SQ 14225), an angiotensin converting enzyme inhibitor, has been shown to be effective in lowering blood pressure of normotensive rats (Bengis et

Received for publication, February 21, 1984.

* Present address: The Second Deparment of Internal Medicine, Tohoku University School of Medicine, 1-1 Seiryomachi, Sendai 980, Japan.

Correspondence and reprint requests should be addressed to : Dr. Minoru Yasujima, The

Second Department of Internal Medicine, Tohoku University School of Medicine, 1-1 Seiryomachi, Sendai 980, Japan. 
al. 1978) as well as hypertensive rats (Bengis et al. 1978 ; Muirhead et al. 1978). Since angiotensin converting enzyme is identical with kininase II (Erdös 1975), responsible for degradation of bradykinin, the hypotensive effect of such converting enzyme inhibitors could be due to bradykinin potentiation. There have been several indirect evidences (Williams and Hollenberg 1977; Mersey et al. 1977; Thurston and Swales 1978) that the affected bradykinin might play an important role in the hypotensive effect. However, chronic effects of bradykinin on blood pressure and the renin angiotensin system and characterization of local bradykinin at the effector sites have not been well documented, making it difficult to further elucidate the role of bradykinin in the hypotensive effect of angiotensin converting enzyme inhibitors.

Recent study from this laboratory has demonstrated that captopril stimulates urinary excretion of kinin, an indicator of renal kinin synthesis or its degradation, in anaesthetized dogs, contributing to subsequent changes in renal hemodynamics (Clappison et al. 1980). Furthermore we characterized bradykinin receptors in rat uterine smooth muscle, frequently used model of vascular smooth muscle and showed that its membrane receptors was down-regulated by endogenous bradykinin (Yasujima et al. 1984).

The present study was designed to determine whether blockade of bradykinin degradation was followed by alterations in local bradykinin at the effector sites, playing a role for the hypotensive effect of captopril. Therefore, we assessed the chronic effects of bradykinin and captopril on blood pressure, uterine bradykinin receptors and circulating angiotensin II, an indicator of the renin angiotensin system.

\section{Materials and Methods}

Female Sprague-Dawley rats weighing $150 \mathrm{~g}$ to $200 \mathrm{~g}$ were used. The rats fed with normal sodium diets were infused with $0.1 \mu \mathrm{g} / \mathrm{min}$ of bradykinin, $1.7 \mu \mathrm{g} / \mathrm{min}$ of captopril or vehicle $(0.9 \%$ physiological saline), delivered via osmotic minipump (Alza, Palo Alto, California, USA) into the jugular vein. The vascular catheter was tunneled subcutaneous$\mathrm{ly}$, and the osmotic minipump was implanted in the interscapular region of the rat's back under anaesthesia of pentobarbitone sodium (Abbott Laboratories Pty. Ltd., Australia). They were divided for different experimental design into three groups; (i) rats for measurements of systolic blood pressure, (ii) rats for ${ }^{125} \mathrm{I}-\mathrm{Tyr}^{8}$-bradykinin binding studies and (iii) rats for blood sampling for measurement of angiotensin II. They were injected subcutaneously with $500 \mu \mathrm{g} / \mathrm{kg}$ of stilbesterol dipropionate (May and Baker Pty. Ltd., Victoria, Australia) daily for 2 days prior to binding studies.

Systolic blood pressure was recorded by means of indirect tail cuff method at daily intervals for up to 7 days of infusions.

Bradykinin receptor binding was assessed at Day 2 and Day 7 after commencement of infusions, conducted such that receptor binding by vehicle as a control was compared to the effects of bradykinin and captopril on the same day. Bradykinin receptor binding studies

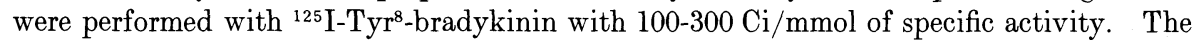
preparation for subcellular fraction enriched in plasma membrane and the determination of specific ${ }^{125} \mathrm{I}^{-T y r}{ }^{8}$-bradykinin binding, were done as detailed elsewhere (Yasujima et al. 1984). The apparent affinity and the number of binding sites were determined from 
Scatchard plot analysis (Scatchard 1949) of concentration dependent binding at initial concentrations from $2 \times 10^{-10} \mathrm{M}$ to $1.2 \times 10^{-9} \mathrm{M}$ of ${ }^{125} \mathrm{I}^{-T y r} \mathrm{~T}^{8}$-bradykinin. Protein content of subcellular fraction was determined by the method of Lowry et al. (1951). 5'-Nucleotidase, a marker enzyme of plasma membrane, was measured as described by Song and Bodansky (1967). The unit was expressed as the amount of phosphate liberated AMP after incubation for $30 \mathrm{~min}$.

Blood for measurement of the circulating level of angiotensin II was obtained with puncture of the abdominal aorta under light ether anesthesia at Day 7 after commencement of infusions. The ethanol extract was measured by radioimmunoassay (Johnston et al. 1972).

In view of the normalization in systolic blood pressure by Day 3 after bradykinin infusion, stability of bradykinin in the osmotic minipump was tested by comparing the vasodepressor effect of bradykinin taken out of the osmotic minipump after 7 days of infusion in a rat bioassay system to that of bradykinin freshly made up, resulted in no difference in the activity between them.

All data were expressed as mean \pm siandard errors. Differences between groups were evaluated by Student's $t$-test.

\section{Results}

Fig. 1 illustrates the response of systolic blood pressure to intravenous infusions of bradykinin at a rate of $0.1 \mu \mathrm{g} / \mathrm{min}$, captopril at a rate of $1.7 \mu \mathrm{g} / \mathrm{min}$ and vehicle alone as a control for up to 7 days. Infusion of bradykinin was associated with a transient fall in systolic blood pressure at Day $1(117.5 \pm 2.8 \mathrm{mmHg}$, bradykinin compared to $125.8 \pm 1.7 \mathrm{mmHg}$, vehicle ; $p<0.05, n=10)$. However,

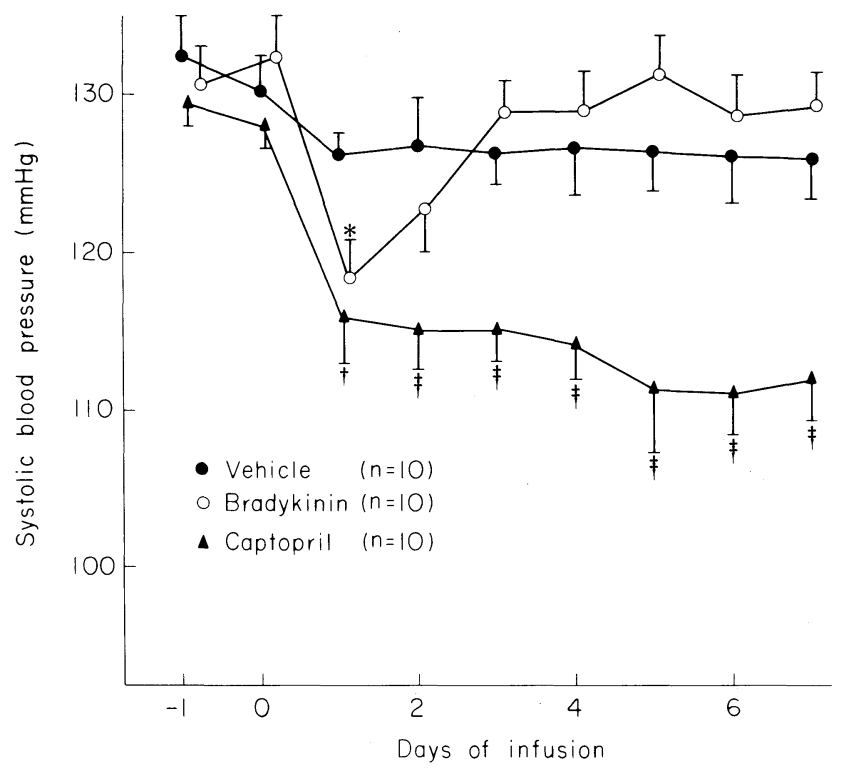

Fig. 1. Response of systolic blood pressure to infusions of vehicle (•), bradykinin $(\bigcirc)$ and captopril $(\mathbf{\Lambda})$ in normotensive rats. Each value indicates the mean \pm SEM of 10 animals per group. * Statistical significance at $p<$ $0.05, \dagger$ at $p<0.01$ and $\ddagger$ at $p<0.001$, compared to the value of vehicle. 


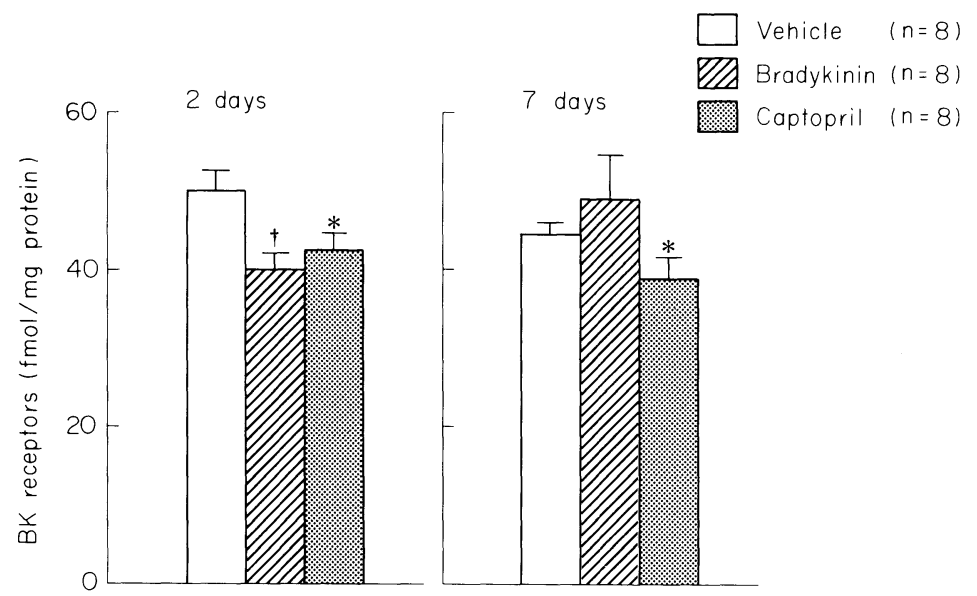

Fig. 2. Effect of 2 days infusions (left) and 7 days infusions (right) of bradykinin, captopril and vehicle on bradykinin binding sites in rat uterine smooth muscle. Each value indicates the mean \pm SEM of 8 animals per group.

*Statistical significance at $p<0.05$ and tat $p<0.01$, compared to the value of vehicle.

at Day 2 there was no significant difference in systolic blood pressure between the rats infused with bradykinin and vehicle alone $(122.8 \pm 3.0 \mathrm{mmHg}$, bradykinin compared to $126.6 \pm 2.4 \mathrm{mmHg}$, vehicle; n.s., $n=10)$. By Day 3, systolic blood pressure in the rats infused with bradykinin returned completely to the same levels as in the rats infused with vehicle alone $(128.0 \pm 1.5 \mathrm{mmHg}$, bradykinin compared to $126.0 \pm 1.3 \mathrm{mmHg}$, vehicle; n.s., $n=10)$. Following captopril infusion, there was a similar but more persistent fall in systolic blood pressure (115.2 \pm $2.4 \mathrm{mmHg}$, captopril compared to $125.8 \pm 1.7 \mathrm{mmHg}$ vehicle ; $p<0.01, n=10$ at Day 1 and $111.0 \pm 2.4 \mathrm{mmHg}$, captopril compared to $125.0 \pm 1.9 \mathrm{mmHg}$, vehicle; $p<0.001, n=10$ at Day 7$)$.

Fig. 2 illustrates the effect of continuous infusions of bradykinin, captopril and vehicle on bradykinin binding sites in rat uterine smooth muscle. ${ }^{125} \mathrm{I}_{-} \mathrm{Tyr}^{8}$-bradykinin binding capacity was decreased after 2 days infusion of bradykinin $(39.9 \pm 2.1 \mathrm{fmol} / \mathrm{mg}$ protein, bradykinin compared to $49.9 \pm 2.4 \mathrm{fmol} /$ mg protein, vehicle ; $p<0.01, n=8$ ). However, after 7 days infusion of bradykinin there was no significant difference in ${ }^{125} \mathrm{I}-\mathrm{Tyr}^{8}$-bradykinin binding capacity between the rats with bradykinin and vehicle $(49.0 \pm 4.4 \mathrm{fmol} / \mathrm{mg}$ protein, bradykinin compared to $44.5 \pm 1.1 \mathrm{fmol} / \mathrm{mg}$ protein, vehicle; n.s., $n=8)$. Even when the ratio of concentration of ${ }^{125} \mathrm{I}_{-} \mathrm{Tyr}^{8}$-bradykinin binding sites to 5 '-nucleotidase, a marker enzyme of plasma membrane was calculated, there was no significant difference in ${ }^{125} \mathrm{I}_{-} \mathrm{Tyr}^{8}$-bradykinin binding capacity between them (Table 1). During captopril infusion, a prolonged decrease in ${ }^{125} \mathrm{I}-\mathrm{Tyr}^{8}$-bradykinin binding capacity was demonstrated $(42.3 \pm 1.8 \mathrm{fmol} / \mathrm{mg}$ protein, captopril compared to 
TABLE 1. Binding parameters of uterine bradykinin receptors during infusions of bradykinin, captopril and vehicle

\begin{tabular}{llcc}
\hline & Treatment & $\begin{array}{c}\mathrm{K}_{D} 29^{\circ} \mathrm{C} \\
\left(\times 10^{-10} \mathrm{M}\right)\end{array}$ & $\begin{array}{c}\text { Number of binding sites } \\
\left(\mathrm{fmol} / 5^{\prime} \text {-nucleotidase) }\right.\end{array}$ \\
\hline 2 days & Vehicle & $6.9 \pm 0.1$ & $700.0 \pm 30.8$ \\
$(n=8)$ & Bradykinin & $6.8 \pm 0.1$ & $536.5 \pm 34.8^{*}$ \\
& Captopril & $7.1 \pm 0.1$ & $555.5 \pm 17.2^{*}$ \\
7 days & Vehicle & $7.1 \pm 0.1$ & $632.6 \pm 32.6$ \\
$(n=8)$ & Bradykinin & $6.9 \pm 0.1$ & $640.7 \pm 16.3$ \\
& Captopril & $7.0 \pm 0.1$ & $465.5 \pm 28.5^{*}$ \\
\hline
\end{tabular}

Each value indicates the mean \pm s.e.m. ${ }^{*}$ Statistical significance at $p<0.01$, compared to the value of vehicle.

Fig. 3. Response of circulating level of blood angiotensin II to 7 days infusions of bradykinin, captopril and vehicle in normotensive rats. Each value indicates the mean \pm SEM of 9 animals per group. *Statistical significance at $p<$ 0.01 , compared to the value of vehicle.

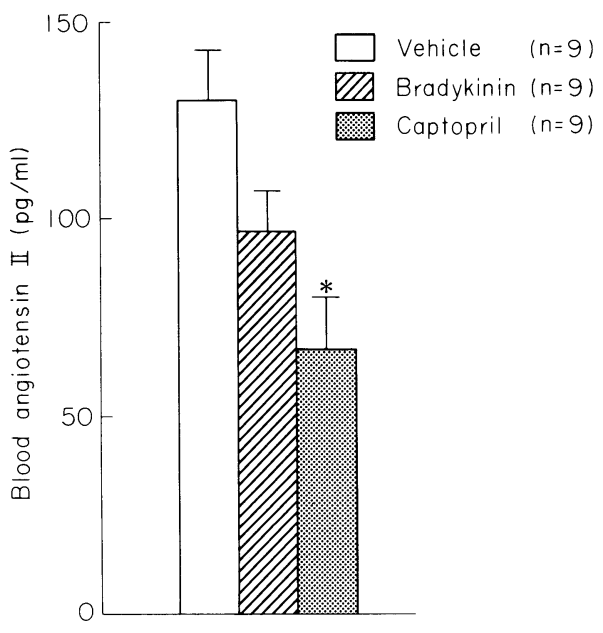

$49.9 \pm 2.4 \mathrm{fmol} / \mathrm{mg}$ protein, vehicle ; $p<0.05, n=8$ at Day 2 and $38.8 \pm 2.4 \mathrm{fmol} /$ $\mathrm{mg}$ protein, captopril compared to $44.5 \pm 1.1 \mathrm{fmol} / \mathrm{mg}$ protein, vehicle ; $p<0.05$, $n=8$ at Day 7 ). There was no change in the affinity of binding sites in any of the studies (Table 1).

No significant difference was found in wet weight of uterus, protein and enzyme component of myometrial membranes among the rats infused with bradykinin, captopril and vehicle (data not shown).

Fig. 3 illustrates the response of blood angiotensin II to 7 days infusion of bradykinin, captopril and vehicle. Captopril infusion resulted in a marked decrease in circulating level of angiotensin II $(66.4 \pm 12.8 \mathrm{pg} / \mathrm{ml}$ captopril compared to $127.0 \pm 17.3 \mathrm{pg} / \mathrm{ml}$, vehicle ; $p<0.01, n=9)$. Bradykinin infusion did not result in any significant change in circulating level of angiotensin II (96.3 \pm 8.6 $\mathrm{pg} / \mathrm{ml}$ bradykinin compared to $127.0 \pm 17.3 \mathrm{pg} / \mathrm{ml}$, vehicle ; n.s., $n=9)$.

\section{Discussion}

Prolonged infusion of bradykinin was associated with a transient fall in 
systolic blood pressure at Day 1 and with return to control levels by Day 3 in normotensive rats. Similar to previous reports (Bengis et al. 1978), our present study demonstrated that administration of captopril induced a sustained fall in systolic blood pressure.

Several investigators suggested that factors other than renin angiotensin blockade contribute to the hypotensive effect of angiotensin converting enzyme inhibitors and raised levels of bradykinin play an important role in the hypotensive effect (Williams and Hollenberg 1977; Mersey et al. 1977; Thurston and Swales 1978).

Recent work in this department showed that captopril did not decrease blood pressure via increasing circulating levels of bradykinin (Johnston et al. 1979; Johnston et al. 1980), suggesting the possibility that local bradykinin at the effector sites, determinants of regulation of blood pressure, may not necessarily be reflected by measurements of circulating levels of bradykinin.

In our previous studies, we showed that bradykinin binds to membrane receptors in rat uterine smooth muscle as other peptide hormones do, and the number of receptors are possibly down-regulated by the prevailing concentration of endogenous bradykinin (Yasujima et al. 1984). Some factors including sodium depletion and elevated blood pressure can affect the number of bradykinin receptors in rat uterine smooth muscle (unpublished observations). According to these observations, the sustained decrease in the number of bradykinin binding sites during captopril infusion could be explained by elevated local levels of bradykinin and/or a fall in blood pressure on the basis of indirect evidence that uterine bradykinin receptors were increased in two kidney, one clip Goldblatt hypertensive rats. Hence, the present results showed that the number of binding sites was significantly decreased after 2 days infusion of bradykinin, while the systolic blood pressure had returned to control levels. The dissociation leads to the possibility that increased local levels of bradykinin rather than change in blood pressure affects more strongly the bradykinin receptors. Unexpected normalization of the number of bradykinin receptors seen after 7 days infusion of bradykinin could be due to secondary changes induced by bradykinin. Bradykinin has been known to cause a marked natriuresis through the secondary changes in haemodynamics (Barraclough and Mills 1965; Willis et al. 1969). Changes in sodium status induced by bradykinin infusion may explain the return of the number of bradykinin receptors to control levels. However, the reason described here would not be sufficient for explaining the difference in the number of binding sites between the rats infused with bradykinin and with captopril, as captopril has also natriuretic action (Bengis et al. 1978; McCaa et al. 1978). It may be suggested that the changes in blood pressure play some role in the regulation of the number of bradykinin target organs. The mechanism remains still uncertain. More data would be necessary to explain the present observation. Collectively, we can suppose that local levels of bradykinin at the receptor sites 
in smooth muscle are increased during captopril infusion and the increase may contribute to the hypotensive effect of captopril. The failure in sustained hypotensive effect of bradykinin suggested the possibility that chronic hypotensive effect of captopril is not due to direct action of enhanced bradykinin on smooth muscle. It is unlikely to suppose that sodium retention, as vasodilators induce (Gerber and Nies 1983), blunt the hypotensive effect of bradykinin, since bradykinin has a natriuretic action (Barraclough and Mills 1965; Willis et al. 1969) as described above. In some experimental conditions, the kallikrein-kinin system is closely correlated with the renin angiotensin system, a vasopressor system (MacFarlane et al. 1974; Wong et al. 1975; Johnston et al. 1976). Flamenbaum et al. (1979) reported that bradykinin stimulates renin release in dogs. However, we could not demonstrate any difference in circulating level of angiotensin II between bradykinin infusion and vehicle infusion, but find the significant decrease after captopril infusion, consistent with previous reports (Johnston et al. 1980).

Bradykinin is commonly known to release catecholamines, another vasopressor substance, from adrenal medulla (Feldberg and Lewis 1964) to modify the hypotensive effect of bradykinin. Furthermore, many reports have postulated that cardiovascular reflex induced by bradykinin affected the blood pressure response to bradykinin (Clark 1979). Therefore, it is possible to suppose that the change in sympathetic nerve tone induced by bradykinin may blunt the hypotensive effect of bradykinin. It may be hypothesized that captopril itself has the attenuating effect on elevated sympathetic tone. Okuno et al. (1979) reported that captopril acts directly on the vascular bed and attenuates the norepinephrineinduced vascular constriction. The hypothesis and evidence may explain the difference in blood pressure response to infusions of bradykinin and captopril in the present studies.

Several investigators have postulated the possibility that the hypotensive effect of captopril may be due to increased prostaglandin system (Murthy et al. 1978; Swartz et al. 1980 ; Abe et al. 1980), since bradykinin has been known to be an activator of the prostaglandin synthetizing system. Schwarz et al. (1980) reported that captopril induced an increase in plasma prostaglandin E metabolite, contributing to its hypotensive effect. Abe et al. (1980) suggested that captopril activates prostaglandin $I_{2}$ in vascular components. The normalization of blood pressure during bradykinin infusion could be explained by the basis of known effects of bradykinin on prostaglandin synthesis with specific reference to $\mathrm{PGF}_{2 \alpha}$, opposing the effects of $\mathrm{PGI}_{2}$ or $\mathrm{PGE}_{2}$ (Terragno et al. 1975; Wong et al. 1977). Therefore it is possible to suppose that the prostaglandin system, stimulated not only by increased bradykinin but by other factors, can contribute to the hypotensive effect of captopril. Recent study by Dusting and Mullins (1980) has shown that angiotensin I had a little stimulating action on the release of $\mathrm{PGI}_{2}$-like substance from the rat mesenteric arterial wall. As captopril increases the level 
of angiotensin I (Johnston et al. 1980), this additional effect of angiotensin I on prostaglandin system can be considered in the hypotensive effect of captopril.

In summary, the increase in vascular tissue level of bradykinin may contribute to the acute hypotensive effect of captopril via its direct action on vascular smooth muscle. However, it may play only a minor role for the sustained hypotensive effect of captopril. Angiotensin I converting enzyme inhibitor has a probably direct action on vascular smooth muscle and activates some other vasodepressor mechanisms.

\section{Acknowledgments}

We wish to acknowledge the help of J. Gannell, K. Sowards and V. Mercuri for their excellent technical assistance. This study was supported by grants-in-aid from the National Heart Foundation of Australia and the National Health and Medical Research Council of Australia. Captopril (SQ 14225) was donated by Dr. Z.P. Horowitz, Squibb Institute for Medical Research, Princeton, New Jersey.

\section{References}

1) Abe, K., Itoh, T., Satoh, M., Haruyama, T., Imai, Y., Goto, T., Satoh, K., Otsuka, Y. \& Yoshinaga, K. (1980) Indomethacin inhibits an enhanced renin release following the captopril, SQ 14225, administration. Life Sci., 26, 561-565.

2) Barraclough, M.A. \& Mills, I.H. (1965) Effect of bradykinin on renal function. Clin. Sci., 28, 69-74.

3) Bengis, R.G., Coleman, T.G., Young, D.B. \& McCaa, R.E. (1978) Long-term blockade of angiotensin formation in various normotensive and hypertensive rat models using converting enzyme inhibitor (SQ 14225). Circulat. Res., 43, Suppl. I, I-45-I-53.

4) Clappison, B.H., Millar, J.A., Casley, D.J., Anderson, W.P. \& Johnston, C.I. (1980) Renal, adrenal, and vascular changes during inhibition of converting enzyme with captopril. Clin. Exp. Pharmacol. Physiol., 7, 493-498.

5) Clark, W.G. (1979) Kinins and the peripheral and central nervous systems. In: Handbook of Experimental Pharmacology, Vol. 18 (Suppl.), edited by E.G. Erdös, Springer-Verlag, Berlin-Heidelberg-New York, pp. 311-356.

6) Dusting, G.J. \& Mullins, E.M. (1980) Stimulation by angiotensin of prostacyclin biosynthesis in rats and dogs. Clin. Exp. Pharmacol. Physiol., 7, 545-550.

7) Erdös, E.G. (1975) Angiotensin I converting enzyme. Circulat. Res., 36, 247-255.

8) Feldberg, W. \& Lewis, G.P. (1964) The action of peptides on adrenal medulla: release of adrenaline by bradykinin and angiotensin. $J$. Physiol. (Lond.), 171, 98108.

9) Flamenbaum, W., Gagnon, J. \& Ramwell, P. (1979) Bradykinin-induced renal haemodynamic alterations: renin and prostaglandin relationships. Amer. J. Physiol., 237, F433-F440.

10) Gerber, J.G. \& Nies, A.S. (1983) Pharmacology of antihypertensive drugs. In: Hypertension, edited by J. Genest, O. Kuchel, P. Hamet \& M. Cantin, McGraw-Hill, New York, pp. 1093-1127.

11) Johnston, C.I., Mendelsohn, F.A.O. \& Doyle, A.E. (1972) Metabolism of angiotensin II in sodium depletion and hypertension in humans. Circulat. Res., 30-31, Suppl. II, II-203-II-213.

12) Johnston, C.I., Matthews, P.G. \& Dax, E. (1976) Renin-angiotensin and kallikreinkinin systems in sodium homeostasis and hypertension in rats. Clin. Sci. Mol. Med., 51, 283s-286s.

13) Johnston, C.I., McGrath, B.P., Millar, J.A. \& Matthews, P.G. (1979) Long-term 
effects of captopril (SQ 14225) on blood pressure and hormone levels in essential hypertension. Lancet, 2, 493-495.

14) Johnston, C.I., Millar, J.A., Casley, D.J., McGrath, B.P. \& Matthews, P.G. (1980) Hormonal responses to angiotensin blockade: comparison between receptor antagonism and converting enzyme inhibition. Circulat. Res., 46, Suppl. I, I-128-I-134.

15) Lowry, O.H., Rosenbrough, N.J., Farr, A.L. \& Randall, R.J. (1951) Protein measurement with the Folin phenol reagent. J. biol. Chem., 193, 265-275.

16) MacFarlane, N.A.A., Adetuyibi, A. \& Mills, I.H. (1974) Changes in kallikrein excretion during arterial infusion of angiotensin. J. Endocr., 61, xxii.

17) McCaa, R.E., Hall, J.E. \& McCaa, C.S. (1978) The effect of angiotensin I-converting enzyme inhibitors on arterial blood pressure and urinary sodium excretion : role of the renal renin-angiotensin and kallikrein-kinin systems. Circulat. Res., 43, Suppl. I, I-32- I-39.

18) Mersey, J.H., Williams, G.H., Hollenberg, N.K. \& Dluhy, R.G. (1977) Relationship between aldosterone and bradykinin. Circulat. Res., 40, Suppl. I, I-84-I-88.

19) Muirhead, E.E., Prewitt, R.L., Brooks, B. \& Brasius, W.L. (1978) Antihypertensive action of the orally active converting exzyme inhibitor (SQ 14225) in spontaneously hypertensive rats. Circulat. Res., 43, Suppl. I, I-53-I-59.

20) Murthy, V.S., Waldron, T.L. \& Goldberg, M.E. (1978) The mechanism of bradykinin potentiation after inhibition of angiotensin-converting enzyme by SQ 14225 in conscious rabbits. Circulat. Res. 43, Suppl. I, I-40-I-45.

21) Okuno, T., Kondo, K., Konishi, K., Saruta, T. \& Kato, E. (1979) SQ 14225 attenuates the vascular response to norepinephrine in the rat mesenteric arteries. Life Sci., 25, 1343-1350.

22) Scatchard, G. (1949) The attractions of proteins for small molecules and ions. Ann. N.Y. Acad. Sci., 51 660-672.

23) Song, C.S. \& Bodansky, B. (1967) Subcellular localization and properties of $5^{\prime}$-nucleotidase in the rat liver. $J$. biol. Chem., 243, 694-699.

24) Stewart, J.M. (1979) Chemistry and biologic activity of peptides related to bradykinin. In : Handbook of Experimental Pharmacology, Vol. 18, Suppl., edited by E.G. Erdös, Springer-Verlag, Berlin-Heidelberg-New York, pp. 227-272.

25) Swartz, S.L., Williams, G.H. \& Hollenberg, N.K. (1980) Captopril-induced changes in prostaglandin production: relationship to vascular responses in normal man. $J$. clin. Invest., 65., 1257-1264.

26) Terragno, D.A., Crowshaw, K., Terragno, N.A. \& McGiff, J.C. (1975) Prostaglandin synthesis by bovine mesenteric arteries and veins. Circulat. Res., 36-37, Suppl. I, I-76-I-80.

27) Thurston, H. \& Swales, J.D. (1978) Converting enzyme inhibitor and saralasin infusion in rats: evidence for an additional vasodepressor property of converting enzyme inhibitor. Circulat. Res., 42, 588-592.

28) Williams, G.H. \& Hollenberg, N.K. (1977) Accentuated vascular and endocrine response to SQ 20881 in hypertension. New Engl. J. Med., 297, 184-188.

29) Willis, L.R., Ludons, J.M., \& Hook, J.B. (1969) Mechanism of natriuretic action of bradykinin. Amer. J. Physiol., 217, 1-5.

30) Wong, P.Y., Talamo, R.C., Williams, G.H. \& Colman, R.W. (1975) Response of the kallikrein-kinin and renin-angiotensin system to saline infusion and upright posture. J. clin. Invest., 55, 691-698.

31) Wong, P.Y.K., Terragno, D.A., Terragno, N.A. \& McGiff, J.C. (1977) Dual effects of bradykinin on prostaglandin metabolism: relationship to the dissimilar vascular actions of kinins. Prostaglandins, 13, 1113-1125.

32) Yasujima, M., Matthews, P.G. \& Johnston, C.I. (1984) Bradykinin receptors in rat uterine smooth muscle: studies using radiolabeled ligand binding. Tohoku J. exp. Med., 144, 107-117. 